\title{
Red Light: Reflections at the Crossroads of History and Art
}

\author{
THOMAS WOLFE \\ Department of History, University of Minnesota
}

The article suggests that Simon Gush's Red is an installation that projects two intersecting paths for anyone confronting it: the path of history, specifically the history of the freedom struggle in South Africa right up to the present day, and the history of contemporary art. The essay is an effort to articulate this position at a crossroads. I respond to the first path by engaging in an exercise of imaginative reverse-engineering. Red seems to invite the viewer to reflect on its own construction and how the different dimensions of its construction might be connected to political meanings and readings. Secondly, I engage in the more familiar work of interpreting an artwork, of saying what it means. I grapple with this task by explaining how Red evokes for me the philosophical problem of ordinary life, as it has appeared in various channels of reflection, from the transcendentalists through the pragmatists, through Wittgenstein and the ordinary language philosophers, through the microsociologists, and down to the present in writers like Stanley Cavell. I argue that a work like this, which operates in and through fragments, points to repair as a central process in ordinary life. The work stages repair by contrasting its object-fragments with filmed voices placed in carefully constructed dialogue with each other. On display is both the fragility of the everyday and the necessity of repair.

\section{Meeting Red}

Perhaps all that can be said with any certainty about a work of art is precisely what can be said with confidence about anything, that it is a thing in a place. ${ }^{1}$ Everything - a film, a happening, a urinal - is an object unto itself, while being surrounded by a world that both provides it with meaning and is at the same time transformed by the thing's active, ongoing existence. The artwork comes into being as an object of interpretation and continues its existence as an interpreted object, changed by the neverending transformation of the discourse communities that both encounter it and seek it out. Art becomes those occasions where we notice this fused duality and, if we care to, explore it, wonder at it. Given the fluid natures of materiality, transmission, temporal scales, society, media, techno-science, government, in the last half-century our world has become full of unprecedented objects and discourse communities making and interpreting objects as art.

1 I would like to thank Helena Pohlandt-McCormick, Leslie Witz and Gary Minkley, who introduced me to Red and made possible my presence at the compelling conversations in East London in August 2015. Their comments on drafts have been very helpful, as were the suggestions of two anonymous reviewers. I would also like to thank Simon Gush and James Cairns for letting me both literally and metaphorically prowl around their art. 
The freeing up of this world of interpretation is what Arthur Danto called our attention to over thirty years ago in his essay 'Modern, Postmodern, Contemporary'. Here he tried to make sense of what had happened to the world of art and art criticism since the 1940s. His argument is that gradually, over the course of the immediate postwar decades, artists stopped viewing what they were doing as in dialogue or relationship with the history of art, and specifically with its most recent coherent current, modernism. This history stopped having any attraction or relevance; artists stopped seeing themselves as inheritors of a history that they had no choice but to reference. Dante noticed that their work was no longer firmly grounded in a past, but existed within a new time horizon that he referred to as contemporary. 'Contemporary art', he wrote, 'manifests an awareness of the history of art, but no longer carries it forward... It is in part the sense of no longer belonging to a great narrative, registering itself on our consciousness somewhere between uneasiness and exhilaration, that marks the historical sensibility of the present. ${ }^{2} \mathrm{He}$ admits that this was a momentous awareness because his entire education, not to mention the institutions that he took for granted like universities, galleries and museums, had been constructed on the premise that their relevance and importance lay in expressing, explaining and exploring temporal connections, the development of a style, the progress of a vision that led from overarching style to overarching style. Scholars and critics held a secure monopoly on the interpretation of the relationship between the thing and the place, and on the particular ways artists grappled with traditions that defined the relationship between them.

By the 1980s this way of understanding the unfolding of art in time didn't feel right to Danto.

But as the history of art has internally evolved, contemporary art has come to mean an art produced within a certain structure of production never, I think, seen before in the entire history of art. Just as modern is not simply a temporal concept, meaning, say, "most recent," neither is "contemporary" merely a temporal term, meaning whatever is taking place at the present moment. In my view, moreover, it designates less a period than what happens after there are no more periods in some master narrative of art, and less a style of making art than a style of using styles. ${ }^{3}$

This art 'has no brief against the art of the past, no sense that the past is something from which liberation must be won, no sense even that it is at all different from modern art generally.' Artists in the postwar era gradually came to understand that all this argument, these serious historical struggles with a tradition, and with the traditions within tradition, were an unnecessary burden. The result turned out to be a kind of liberation: 'artists, liberated from the burden of history, were free to make art

\footnotetext{
Arthur Danto, After the End of Art (Princeton: Princeton University Press, 1997), 5.

Ibid, 9.

Ibid, 5 .
} 
in whatever way they wished, for any purposes they wished, or for no purposes at all. ${ }^{5}$ The art made in this ongoing contemporary moment is 'post-historical art', and as such is free to be injected into just about any setting, tied to any cause, acting on behalf of anyone.

Danto's essay appears dated in its references, of course. The artists he refers to are important for the way they use photography, but an updated version would probably stress the mediums of Red: the installation and the video. Moreover, it is obvious that the article is responding to and making sense of the host of forces and developments that we have grown accustomed to by throwing them into a box labelled 'postmodernism. But what Danto was trying to glimpse and give a name to in the 1980s seems today a part of our common sense. The artwork, freed from necessary but burdensome reference to modernism, is free for all other kinds of purposes and interventions. Art can be directed along all sorts of vectors and can sketch all sorts of trajectories. It is as variable as the social contexts that desire and consume and value these complex objects. Perhaps most importantly, the art world is no longer managed through a closed world of connoisseurship, but is about the communities that coalesce around objects, that seek them out for reasons and logics of their own, and conversely, that are drawn to certain objects because of their particular resonance and power for that community. Viewers participate in interpretation if they care to. This is what makes contemporary museum going so exhausting: a museum might decide to exhibit a range of its collection, placing in the same gallery a grainy video, a dwelling space knitted out of coloured rags, and in a sink a bloody knife stained with what could be blood - various art objects, each evoking different realms of language, discourse and emotion, and each offering and demanding something in turn. Understandably curators give a lot of attention to the experience of the gallery, making the gallery itself into another art object.

But what of Red? On the surface, the interest in it shown by a group of scholars of South African history is obvious. It is about South Africa's recent past, about a charged moment in it. The work consists of two items whose historical references are clear: a handful of car parts that refer to the red Mercedes given to Nelson Mandela in 1990 as a gift from the workers in a Mercedes-Benz plant in East London, and a video of interviews with a handful of key participants in the labour struggles that took place in the East London Mercedes plants in the late 1980s and early 1990s. The obviousness of what it is about enables the kinds of concise summaries that marked any number of documents the organisers composed in the course of arranging the conference, and that we see in their introductions to the issues of parallax and Kronos where several essays on Red are brought together for publication. ${ }^{6}$ After all, a work has to be introduced, a conference has to be about something. And yet this aboutness is just the problem, because Red is only about these things in the particular ways given by its artist maker. And here is one tension that I want to explore in this essay. The

5 Ibid, 15.

6 Helena Pohlandt-McCormick, Gary Minkley, John Mowitt and Leslie Witz, 'Red Assembly: East London Calling', parallax, 22, 2, 2016, 121-31; 'Red Assembly: The Work Remains', Kronos, this issue. 
work, I would argue, is characterised by a split between a critical political/historical awareness on the one hand, and on the other a kind of repose, indeterminacy, slowness, distance and openness that comes from the particular choices that we can call artistic. (This split was also running through the experience of 'Red Assembly', the two-day conference that took place in August 2015. Participants were invited to display their stance, or better, find their footing, at this intersection or crossing.) I want to first describe this tension and then move on to give some idea of how I put Red to use as I looked, listened, puzzled and enjoyed.

First I should say a few words about my own perspective. I work in a department of history at a large institution in the American midwest, where I teach history and something much more amorphous called 'global studies'. The time and place of my studies is the twentieth century and Europe, although for me both categories are indeterminate. What I bring to the interpretation of any kind of visual, literary, historical, artistic object is a familiarity with the tensions, antagonisms and conflicts that produced the ideological, conflictual and political national landscapes from the early nineteenth century on. Particularly conspicuous in this history is the growth since the mid-nineteenth century of socialist philosophical thought and political praxis that so decisively shaped modern politics. This discourse and these movements have been global, and represent for me the particular modes by which modern societies struggle with utopian desires in eras of unprecedented techno-scientific change. The Soviet Union stands out for the ways it served both to deepen and broaden a 'Left' and to constitute one half of the rigid geopolitical opposition that marked the global Cold War. Building on nineteenth-century European socialist thought, and grafting its ideas onto local traditions of autonomous, egalitarian communities, Soviet leaders organised the wholesale transformation of Russia's political, economic and cultural life beginning in the 1920s, and beyond its borders began to sponsor the worldwide network of activists working for socialist transformations in former colonies. Central to this immense development was the construction of a media system in the Soviet Union that worked to align the thinking and energies of a vast illiterate population. Arguably at the core of the country's symbolic repertoire was the colour red, which came to evoke the worldwide power and presence of communism. For someone interested in this global history, a work of art entitled Red was an instant object of curiosity, especially as it concerned a place where a communist party played a central role in the country's recent political transformation.

It was also clear, however, that whatever specific meanings resonated within that simple name, they did so for specific African and South African reasons enmeshed in local cultural and historical terms. A work called Red would resonate differently in East London from one created in the former East Berlin. Outsiders could be said to face a problem of 'colour blindness', of not knowing the full extent of the associations implied by concepts like 'the left', 'communism', 'radical', 'postcolonial', 'progressive', and of course 'red'. The familiar danger is to re-enact what emerged early on as a key problem for socialist movements, the tendency of the literate and educated to speak for the illiterate, the uneducated, the racially subjugated, without really understanding their points of view or everyday experiences. This structure of condescension 
was repeated after decolonisation in the project of development and international aid which promised a rapid exit from backwardness. But problems of democracy will always be there for everyone to think about, and so will the unequal opportunities to speak about the conditions of contemporary life. And not all outsiders are always ignorant, always clumsy; one solution is to approach these issues with an amalgam of seriousness and playfulness that might with luck offer something unexpected.

As mentioned, Red moved in two directions at the same time through the installation and the video, offering connections to two different discourse communities. These two intersecting routes, arriving from and heading off to completely different places, were sited in one installation space, with the viewer at the crossroads. Thus anyone who comes into contact with Red will tend to see it in one of these two ways. This structure had consequences for the 'Red Assembly' conference, which itself constituted a kind of crossing for its participants, with everyone trying to find their own entrances and exits, their paths into and out of the work. On one level we brought the discourses of our own educations to Red, and yet despite our heterogeneity it seemed to me that we tended to feel the pull towards these two intersecting interpretive positions: one grappling with politics, race, and power, the other being about the senses, technology, time and memory.

For the former, Red referred to the history of struggle and consciousness that frames the most important political phenomenon of the twentieth century, the emergence of a conscious class of people who understood their role as 'labour' in capitalism's global structures. Here historians play a key role in interpreting the past for future activists and members of the public whose political awareness and convictions need shaping. At stake for them is the success or failure of the democratic transformation that was the struggle against apartheid. These historians would take Red to be about different moments in that struggle. They ask about the history of workers, what to make of that episode of Mandela's red car, which naturally shades into 'What to make of Mandela?' They would view the video part of the installation as a collection of oral histories that shed light specifically on industrial conflict and thus contribute to a wider account of the role of trade unions in the collapse of apartheid. These oral histories show the story to be intricate, full of personal idiosyncrasies and jealousies, revelatory of the way this transformation was a global process that included transnational corporations and their labour policies, as well as local activists.

For such historians Red would not be particularly important or interesting as art. In fact, most researchers of labour movements, or trade unions, or the social lives of the working classes, don't write much about art. For them, the history of art is done elsewhere on campus, where scholars practise a completely different discipline. Sure, social or political or economic historians might use a piece of art - a painting, piece of sculpture or short story - to illustrate something; they might assert that a Works Projects Administration (an American New Deal arts organisation) photograph from the 1930s is about poverty, say, or is a symbol of something like class tensions, boom and bust cycles, or the power of ideology. But in general their interests take them far beyond anything as solitary and particular as a single work. Their vision appears broader and wider, the forces they are trying to chronicle operate on the scale of 
entire nations and societies. They might write in a history of postwar America that Warhol's silk screens and Brillo boxes offer a critique of postwar consumerist culture, or that these objects identify and denounce the commodification of everyday life. But an economic history of the New Deal does not need a Dorothea Lange photograph any more than a study of Brueghel's style has to refer to the politics at the Hapsburg court. These are different interests, different aims. Historians of this kind might even argue that too much thought about art can distract from the real, necessary purposes of education and mobilisation.

What of the other track Red suggests, its art? It is, after all, an artwork, created by someone who considers himself an artist, for an audience of people who visit galleries to experience art. The work was discussed in art circles and clearly resonated with a different community of historians, those interested in art as experience, and art as part of, rather than in negative relation to, the work of education into democracy. These are the people delighted to see that the East London Daily Dispatch ran a headline on the day of the exhibition's opening at the Anne Bryant Gallery reading, 'Famous Mandela Car Gets Arty', since 'getting arty' is a way of thinking and creating new insights. Understanding the post-apartheid dilemmas of South African society requires citizens to encounter not just the narratives of historians but also the experiences created by artists, ones that can at times be disorienting, opaque or obtuse but that can also reward the effort of interpretation. These cultural historians might say that Red is indeed about Mandela but not Mandela the political figure. For them it is about the construction of Mandela's image in the media, history texts and popular arts, a product of forces and technologies whose afterlives constitute the dilemmas of the post-apartheid moment. Red is about stories, yet for some it does not really offer an archive of oral histories. In fact they might point out that these clips don't look like oral histories. The video in Red is neither amateurish nor Ken Burns-like. Its subjects are presented not as experts but as explorers of their own memories.

In Red's interviews, there is no hallowed setting for recall, no unidentified library or club, or any authenticity-creating subtitles to speak of. There is no historian present, not even any 'historical' interest expressed, no researcher lurking just off screen digging, prodding, guiding, channelling the process of recall. The talking subjects are certainly looking at someone and responding to something, but this someone and something seem absent. The shots are artfully composed, not rushed or hurried or casual; there is nothing dramatic about the lighting or setting. In short, there is something in the visuality of the film that demands attention, something we feel is the product of skill, effort, thought and talent.

If the nature and portrayal of these interviews are shaped by interests that can best be described as 'artistic', then the artistic is even more present in the scenes of East London that are interspersed throughout the video. Here are scenes whose importance could only be puzzled through by grappling with the film's aesthetic argument. They seem to be more than simply illustrations or reminders that this is where the labour history these men are recounting is taking place, this is what East London looks like. Rather, these are unmistakably statements intended for reflection that could in fact be seen as a deterrent to seeing this as purely historical, sociopolitical narrative. 
In short, a lot was going on at this crossroads, and the real task was to sort it out. Eventually I felt two different needs. The first was to somehow demystify Red, to deflate its inscrutability by grounding it in a story about the mundane experiences of its makers. It seemed possible to give an account of Red by imagining how it came into being. This would be a story that tried to appear as faithful and as plausible as possible to the evidence of the finished object, but that would at the same time have to take licence, improvise, create out of whole cloth. The task, in other words, would be to clarify Red by reverse engineering it, by imagining the mundane steps of its construction. There would be principles to follow and dangers to be aware of. As one engineers in reverse one must be as neutral as possible, stay open to the overwhelming pressure of the practical and to the accidental dimensions in any kind of making. For in the background of Red were all manner of mundane moments: the endless editing of video footage; puzzling over what the car chassis was to rest on; getting the phone numbers of junkyards to find usable parts - imagining a set of steps that, in the case of an artwork, would be ones of possible feeling or conviction, which can only happen with empathetic attempts. This story would be fiction but it would provide some leads into the verifiable past. The chief danger would be conveying the impression that I understood the work better than its makers did, something manifestly not true. I did not want to speak for anyone or on behalf of anyone, and yet imagining audiences and possible receptions and interpretations is inherent in working through any process of making. Another danger was implying that Red was easy, and yet to reverse engineer something is indeed to put clarity on display, to suggest that anyone of reasonable intelligence could do it. Thus the risk of sounding too breezy, yet this was unavoidable if the goal was to illuminate the work by putting its process on show.

The second urge I felt was to describe how Red spoke not only to the immediate context of South Africa, but also that it might have something to say about everyday predicaments and the repair of ordinary life. These two themes are my responses to finding myself at such an intersection of history and art.

\section{Making Red}

Two men get off a flight from Johannesburg to East London, Eastern Cape. One is tall with blondish, tousled hair, the other shorter, stockier, with a squarish face. They rent a small white Ford, the cheapest on offer, and put into the boot their four small suitcases filled with clothes and equipment. They are here because of art. Which means they don't quite know what they are after, only that it is necessary to be here, that they need to spend some time taking video and talking to people in this place. They have come because of the famous red car, Mandela's car, which was built here. Somehow that red car drove itself into the artistic consciousness of the taller man, he started to roll it around his mind, and here they are. The car was built here, in East London, where Mercedes-Benz had and still has a plant.

Both men know art not just in the sense that some education and years of selfstudy enable you to know art, its history, its makers and styles, its creative geniuses and economic organisation. No, they know art in its insides and its adjacencies. 
The taller one knows how art - the contemporary kind, that is, the installation art, the performance art, the happening art - actually holds together long enough to be looked at. He knows art's engineering, how the tree trunks can be made to appear just walking up the white wall, how the 800 fans are powered, how to hold those steel shards with welds. The shorter one knows the video art that is mass produced by studios whose writers are paid by the word, whose producers rewrite the scripts, whose stars are mostly empty-headed, and whose financial viability is everything. This means that they know how to make things and make them well. They know cameras and images, and they know objects and spaces; and when they have had time they play around with these, knowing that there is something free and open in all this, something to be done when no one gives any orders or when there is no advice to be followed but only instincts.

They are not sure what they are doing. Or rather, they are not sure what they are looking for. They have been to East London a number of times, but after leaving the airport they quickly grasp that what they are after is right there, can't be missed, is right there next to the harbour: the territory of the plant with its gates and railroad tracks and buildings in various states of use and disuse. There it is yet there is no chance at all of gaining access to it since they have no permission, are not connected; they meet the world of automobile production as complete outsiders. They get the camera out - basic, bottom of the line camera, as everything will be moved to computer where the real images will take shape, they are mining for the raw materials - and start filming. Camera on a tripod, choose a certain perspective, record for 30 seconds. Zoom out a bit, 30 seconds. Include the benches, 30 seconds. Now without the benches, 30 seconds. Back into the car, find the way to over there, to that street across the river. At times they must hurry since the scenes around the factory have so much to offer; one of those behemoth RORO vessels (roll on-roll off) is about to enter the harbour, about to go past the enormous deserted beach, and because the tide is out, and with the telephoto, the ship would look even more enormous than it is. As they are driving from place to place looking for a place to set up the tripod, they ring the handful of cell phone numbers they managed to scrounge up before leaving home, names of people they might be able to interview, to get on film, since that is the other footage they are after. Since art is artfully arranged. Fragments, that is what they're after: situations where they can produce their fragments. About the car. About the red car.

They are not after the history of the red car. They are not historians, after all. Nor are they sociologists, cultural studies scholars or political economists. They are not academics. Nor are they activists, investigators from COSATU or the ANC or the government or the opposition, or from the tiny anarchist grouplets in Johannesburg. Being artists, they don't have to pursue what these other kinds of people usually do. Best of all, they don't have to be truth seekers, there to get the actual story about the red car. And yet the car is indeed the reason they are there.

These men were kids when Mandela returned from Robben Island and apartheid began to fall. They remember these events, or remember as we remember events that are displayed in a relatively small number of endlessly replayed clips shown on TV, 
but they were not old enough to understand that their entire lives would be dominated by this change, this transition, as some nice people found a nice way to call it. And indeed that is why they are here, because they feel the question as strongly and urgently as everyone else: what is happening to the society? To the country? What sense can be made of a history that seems rightly called a history of liberation but that has become a process of just living with poverty and inequity and scandal and stupidity, everything that the liberators assumed and promised would go away? As has been the case in transformation after transformation, no one ever really got around to figuring out what would happen the day after the revolution, the day after Mandela's victory, and like everyone else in the society they can only think about this in the handful of moments when they are not consumed with the work of putting food on the table, making ends meet. But when they have time to think as artists they know these changes demand art, a lot of it.

The one thing they know for sure is that they don't feel like more history, because they have completely lost faith in historians. This attitude has guaranteed they will face hostile situations. How does your so-called art, they will be asked, amount to anything useful for change, since no one can understand it? Just a bunch of stuff put in a room and given an enigmatic name. That might please the clever academics but activists can't explain it to the masses, and in fact, why didn't you ever learn that after real upheavals, artists have to keep returning to the unending task of making the change real? And that the fate of artists who live in their heads is exile in Paris, New York, Mexico City, wherever they can excavate some sustaining corner of 'the art world. The shorter man doesn't give a fig for this sort of talk; he considers it quite amusing. The taller one is more used to the verbal posturing involved in these interactions and he has various kinds of responses, although he rarely voices them publicly: that the art you think moves the masses in fact doesn't move the masses. That the decadence of the art world is just an imitation of the decadence of the political world, especially the left political world. That insights into history have long since ceased to be the product of historians, given all the compromises, habits, constraints, temptations and deceptions required for academia to operate.

The fact is they are there for the stories, stories that will be recorded in AVI files that will provide the stuff they can work with on computer, where the thing that people will someday see will take shape. Stories. What will they get when they find the right people to talk to? What will they be told? They have read up on the History of the South African Automotive Industry. They have read up on Labour Relations in Transition. They have read up on Globalisation and the Radical Trade Unions of South Africa, and a lot more. And so they are informed in a general way about what happened and continues to happen behind the fences they have been circling in their small white Ford, around those enormous buildings that say things like 'MercedesBenz South Entrance' above their gates. They know, for example, that they are wading into one of the most important terrains of the liberation story: the work the trade unions did to foster grassroots militancy in the factories, militancy that proved invaluable for pushing the tottering system into final collapse. And because they were interested in the car, the red car, it would mean asking whoever they could find to 
think their way back to that moment nearly twenty-five years ago. How many people with a lot of potentially powerful things to say about the car have died since then? Answer: a lot. And of course they know but don't care that memory isn't perfect, that people tend to remember their actions in self-justifying ways, that complexities get ironed out, ignored, subverted, that people's misgivings and fears usually are omitted in the act of telling. In front of a camera people tell history as if it is all pretty clear what happened. But again, that was OK for the two men; fragments was all there was.

One person answered their phone call. They spoke, they filmed, and that person recommended another two. They knew that the factory that produced the car was a space divided into two, workers and management, and so they called people from both realms, not knowing if anyone was even still in town who could provide the management's fragments. But they found people, who recommended others, and slowly the archive grew. These people told great stories. And once again, the fear of not having enough turned into the excitement of having too much. At the beginning they went straight for The Car, but then they realised that the car was just a moment, and that what happened on either side of the car was as important as the car itself. So the film, the imagined film that would be the physical whole of these fragments, started to take shape: the labour situation in the East London Mercedes-Benz plant, the story of the car, and the denouement of the conflict between SAAWU and NUMSA, the two trade unions that represented East London's autoworkers.

They had tried to shoot all the interviews in the same manner, with their subjects usually sitting behind a desk, or next to a desk, or at a table, that served to make each person a 'figure', someone in and of a workplace, even if they had long since left the workplace of 1990. They asked everyone broad, open-ended questions so that they would have to speak in long accounts full of details and explanations and anecdotes. They would be serious so their interviewees would be serious too, would start to try to remember, would realise that indeed, here is a story worth being told of that era in South Africa, an era that seems so long ago but was in fact just yesterday, and that was undoubtedly part of the larger proud history. They would make their interviewees feel that indeed, they had made history, both the black workers who had shown class and race consciousness in the apartheid drama's final act, and the white management whose insistence on smoothly running labour relations could be read as the kind of thing South Africa would have to understand if it wanted to join the world economy.

This seemed like a plan because they heard some pretty interesting things. Köpke: 'We had to start a revolution, meaning a revolution to create obedient workers, since it didn't take much to sabotage the production process, just a key scratching a door. Groom: 'We had a saying back then: you had to leave your brains at the gate, and bring only your hands.' Russell: 'People started to ask themselves, "What would it be like without Mercedes-Benz?" And "A factory is a reformist institution, not a Marxist institution."' Then we see Groom, who seems to be the person responsible for the red car, recall the very moment when the idea of the gift hit him: 'Hey Vito, the old man is out now. You know, he's got no car. We need to build a car for him. Nelson Mandela offered up 27 years of his life. Let us do something for him and I propose we build a car. But I say we have to build the top of the range, you know?' Russell smiling 
with what appears deep, ironic pleasure: 'The AK47 has been replaced by the Red Mercedes-Benz.' The capture of Mandela by ordinary life: Köpke saying, 'I obviously swapped that car six years into its life with a new Mercedes S class. The new car was nothing, but Madiba's red car was sensational. These memories of those events were intense little shards of experience, given a moment by art.

There was still a problem in the tall man's mind, though: What to do about the thingness of the red car? Was it enough to simply make a film about it? Nearly every South African knew that the car, the real car, existed in the Apartheid Museum in Johannesburg. This was the car the workers made for Mandela, and whose story was a part of the museum's story. What to do about the car? There was art to be made of it, but what? How? Perhaps the problem with the real car in the Apartheid Museum in Johannesburg was that it was too real. Sitting there in front of a nice display with text and pictures, here is not The Car, but just a car, stalled in the work of commemoration. And since every museum is a kind of prison, then isn't this car more like a hearse, a red hearse, a prison vehicle for Mandela's spirit, one seeking a way out of our memory system, a way back to the village where his father had been chief? So how do you let the spirit out? By dismantling the cage. Not just opening the door, but removing the doors altogether. Keep the car but open it up completely, show some of the heavier, more beautiful things that could say to the viewer, here is Mandela's car but he is not here.

It was a short step from this to the idea of deconstructing the car itself, which would also be a construction of an image of work, since parts are a brilliant reminder of the materiality of alienated labour, of the worker's daily lot of lifting, painting, bolting and finally polishing these awkward dangerous things of steel into place so that they can play their role in the consumerist obsessions of this luxury-seduced society. It was a Mercedes after all - not a Ford or a Toyota, but a Mercedes, the mark of luxury and quality. So, in addition to a film, put a big red commodity form in a gallery space. Maybe the image of the chassis and the hood and the doors exhibited on the walls of an art gallery wouldn't leave the taller man's mind because he concluded at some point that it was really all about things in pieces, which in fact might be the best metaphor for society at this point in time: a bare semblance of a whole, really just pieces.

All of this jostled with the film as it slowly started to take shape in the course of hours and hours of editing. They gathered these two very different kinds of footage. But what to literally make of it? And what attitude to take, as artists, to all this storytelling, all this memory work? What is art doing here, anyway? Well, two very different kinds of film can interrupt and disrupt each other. And if part of what they are perceiving and grappling with is the problem of the temporal drift between the postapartheid now and the historical moment of liberation, perhaps the interviews could be disrupted with brief temporal invasions of place, interruptions in the story that sometimes would be more or less straightforward references but that at other moments might be more difficult, confusing and jarring. The film could mess with time by adding to the two normal, common frames (the time of enunciation, captured on film, and the time of history, conveyed in their subjects' speech) a third frame, a 
time that is an unclear time, unfocused, uncertain, the time of the harbour, of a passing ship, a street corner, buildings and parking lots. A time of the shot, as a sign of the pure contemporary. Not just any places from any city but places of East London, ones that would be recognisable to its citizens as their places. These nearly still scenes would have to be long enough to really capture the viewers' attention, to derail the coupling between interpreting the aural, the articulated words, and interpreting the visual, body, scene, posture, gesture, by suddenly removing the visual and replacing the speaking body with a murmuring landscape. The voiceover would continue while viewers had no choice but to integrate into the narrative those background sounds of outdoor scenes, foghorns, waves, trees, traffic, each of which has all sorts of semiotic potential for heightening or disrupting or commenting on the story being told.

There were undoubtedly some risks here. Too brief, and these scenes would appear as something cute or coy; too long, and they would appear heavy handed, as if the scenes of the contemporary were what were the stories were about. How long was long enough? At least twenty seconds but not longer than forty. Perhaps the idea was to have the scenes somehow infiltrate the storytelling with their very stillness, their anonymity and almost indifference, pulling the viewer up short, like a little yank on a chain meaning don't go there, don't be fooled into following the trail down that gulley, because we are talking about an impossibly complex present moment. They could work with some warnings.

In short, as they began the editing, they immediately faced the question of how to manage the pedagogy, how to constrain the lurking presence of the didactic. There were moments when it seemed they should link story and scene more tightly together, draw them towards each other in a more familiar kind of reference. For example, when discussing the repercussions of the plant closing, they show pictures of city streets with cars passing by, a building, a passer-by, as if to say, this is the world that is being talked about here. And when Mandela's release is discussed, the images are of churches, connecting the event with the particular places that are scenes for rituals of spiritual intensity. Towards the end of the film, when Thembalethu Fikizolo mentions the social prestige of the Mercedes-Benz workers out in the community, including stories of the girls who liked to party with them (since these workers were the ones who had some money and could afford to show a little style), the images switch to night and the dock where row upon row of vehicles wait their turn to be loaded onto the ship. This then makes a nice transition to the discussion about the 'sleep-in' strike, when the militant workers tried to make themselves at home in their occupation of the plant, an episode that returns as offering something more, as we shall see. So it seemed natural and necessary for some of the footage to illustrate the stories.

One can imagine their pleasure as they realised that of all the narrated episodes that offered the best opportunity for meaning-making, the most potent was the story of the car's presentation. Here was the narration of a jubilant moment, of pride and pleasure on the faces of the interviewees as they tell of the helicopter bringing Mandela, of the speech that the nervous Groom gave and then Mandela's gracious response that those who were there will never forget, of Winnie Mandela's claim that the car is hers, her reminder that he does not know how to drive. In the mind's eye is 
an image of a large, jubilant crowd, ecstatic to be in Mandela's presence and to be the gift givers to such an important figure, one on whose shoulders their fate rests. But what to show? A sudden cut to an empty stadium (perhaps the same stadium?) - just an empty stadium on a blustery day, one of the loneliest and most desolate sites in a modern city, a scene overflowing with absences: hundreds and thousands of absent spectators, players, journalists, fans charged with excitement, desire, yearning, perhaps violence, and producing above all, noise, spectacle, and hope upon hope. But now the camera frame is full of absence, and there in the middle of the empty stands, in the very middle of the angled series of roofed-over rows, they show what looks like a single person just sitting there, still, alone, radiating solitude and, in this setting, anguish, probably contemplating something lost, thinking about what to do, how to save a situation, where to go, how to escape, what to say.

It is easy to imagine that at this point in the making the two men, sitting by their computer, might have had some heated discussions, since in such juxtapositions it always seems that a moral wants to loom into view. Did they want to be so direct in stating that the dramatic places of History always end up empty, and that the silences in those places can be absolutely deafening? Did they want to insist on the inevitable return of planned and produced spectacles to silence, since the production must always move on before it cycles back. And here again was the question of what dramatic historical changes leave in their wake, in this case just an empty space, a darkness descending on structures. The moment might become an episode in the life story of the participants and in the works of professional historians, but the place itself has no memory of anything.

Finally, as they edited the film, they began to wonder, could something from the stories somehow step out of the film, break the frame of projected image and represent a full presence in the gallery? Could there be one additional set of objects besides the doors and the hood and the chassis, to work on the visitor, one more challenge to decode? Some things that would play off of the meanings of the dismembered car? They remembered the story about the last, desperate, useless strike where the workers occupied the factory, refusing to leave, sleeping there on whatever they could find that would serve as mattresses and blankets. They watched again the footage in which a union leader tells how they slashed open car seats to get at the foam they could sleep on. Here was an object just waiting to have quotation marks placed around it, since it was a turning inside out, a putting to use of what had been so inverted. Here were things used but also distorted in the process; after all, to turn something inside out is both an act of revelation and of destruction. The viewer could put together a thought in all this twisting and opening: ending apartheid turned society inside out, but in the course of inversion, key lines were cut that changed the nature of the thing.

So another set of objects was added to the installation, resulting in a pleasing three-legged stool: film, car, stuff. The viewer would have to adopt three modes of interaction: spectator, appreciater, decoder. Film was edited, car parts found, symbols framed. The work took shape after months of editing and engineering. At some point, one of the two men said to the other, "Enough! Here is a work that will roll on its own!' 


\section{Ordinary Red}

So at the crossroads, having gazed up and down one avenue, we can now turn a slight 90 degrees and take in another scene, engage with another discourse. Now we might let go of the reverse engineering, the telling of a story and turn towards meaning. Or rather, we might tell another kind of story, not about South Africa but about life. We might slow down and take stock of this dense red object in order to say something else, to put it to a use that is not about emplacement in a history but rather as displacement into our common condition. The two men might find these abstract thoughts curious, although perhaps they would also feel some satisfaction, since orienting or supporting thought is one thing that art can do.

What I noticed in Red - in its concepts, its contents, its stagings - is something that I want to refer to as 'ordinary'. This is an odd word, and I don't mean it in the usual sense, since a multimedia art installation is hardly an ordinary object in the same way that a pair of scissors or a lamp are. Take the word not as an adjective, but as a noun in the way it has appeared in various areas of reflection from the transcendentalists through the pragmatists, through Wittgenstein and the ordinary language philosophers, through the microsociologists, and down to the present in writers like Stanley Cavell. I am reading Red with a particular text in the back of my mind, the French philosopher Sandra Laugier's introduction to a special recent issue of the journal Raison Publique titled 'The Return to Ordinary Life.' These writers are not political philosophers. In fact what unites them is the conviction that any kind of macro-politics must be based on an accurate understanding of the social constitution of experience and on the ways that values can be searched for and found in the midst of life happening. The ordinary appears as an interesting and important concept, in moments and places where politics of the more familiar red variety - the politics of movements, ideologies, and macro-categories like class and nation - seem in question, seeking purpose and orientation. And this is what I find in Red: raw materials to work with in such a reorientation. Against the grain of History or the Event, the film brings us down to this more mundane place.

Red is an organised display of something taken apart. The parts are not placed to evoke their eventual assembly achieved in the course of a complicated industrial process, but are simply a number of unique objects that seem to make no sense apart from their participation in a whole. The objects bring our attention to what is normally taken for granted, that we interact with and understand automobiles in the simplest of ways, as something that gets us from here to there. Here we are reminded of one of Latour's starting points, that we only notice the thing-ness of the world when something breaks or stops working in the automatic, thoughtless way it should. We notice the invisible automaticity of the world when things are out of place, when they do not meet each other in their normal ways, and when we see that which is never normally seen. Gush has neatly and deliberately broken things; we look for words in negotiating these dangerous and seductive fragments, but we can also find here an invitation: 'The interrogation of the ordinary appears when our words, or our lives, lose their meaning, and we have to learn to find them 
again.7 This loss of meaning might be what is going on in the course of visitors strolling around Gush's car parts, looking for the words to articulate the strangeness of this disassembly but not finding them. 'The ordinary hangs by a thread,' writes Laugier, or, we could add, by a weld. ${ }^{8}$

But these things, these parts, are just a kind of prologue and reminder. They advise the visitor: take nothing for granted, you are going to have to put in some effort as you stop and sit on the low benches in the darkened room where the filmic part of Red loops round and round. For here is a different kind of statement. Laugier reminds us: 'The ordinary exists only in this difficult means of access to that which is right before our eyes, and that one must learn how to see. It is always an object of inquiry ... and of interrogation, it is never given.9 So what do we see, if we take the time to give ourselves to the task of learning to see this film? A kind of inquiry, a staging of speaking subjects that is not a narration but rather a cooperative, constructive conversation, the kind that ordinary language philosophers and sociologists identify as necessary for the ongoing work of repair of situations always tending towards collapse. Indeed this is what is uncanny about the interviews, for they are not so much about events as about their recall and reverbalisation in a powerfully marked, if undefined, present moment. The film does not take sides in the disputes it narrates, it does not seek to portray the actors in any particular moral light. One hears in every voice a similar tone and timbre: fatigue, resignation, disappointment, pride. The stories are told without much investment or charge, with very little anger or resentment. This is a particular kind of speaking: not a Habermasian, rational clear channel, but a Wittgensteinian building of mutual worlds and forms of life. We feel that for these storytellers that era is over, it resides deep in the past and in memory although, strangely, it can be recalled as if it were yesterday. There is also a confessional quality to the speech, as in, yes, we did that, we did that, both sides doing what made sense at the time, but that with time, measured by creases etched into faces and holes added to ever lengthier belts, their actions become just events, what one did with one's life, what happened to you and what you made happen. Even the entrance of Mandela into the story happens with a modest pleasure and pride: 'Let's build the old man a car.' But again, we do not see and hear them telling what Mandela's release meant for them, or what it meant and means for South Africa; rather what we have is simply another episode, one whose significance was also just an event. In fact the red car is not really what the film is about, what it centres upon, for the film has no centre; it drifts into this story and then drifts out of it, reminding us perhaps that the rhythms of political events do not at all coincide with the rhythms of everyday life. There are only brief, confusing and meaningful moments of overlap or intersection.

The video can be seen as a staging of historical repair, the kind of repair that is not heroic in the socialist sense of the unfolding of a historical logic, or in the psychological sense of coming to epiphany. The drama of these events is as it were domesticated,

S. Laugier, 'Introduction', Raison publique: Arts, politique, et société, 18,Printemps 2014, 14.

Ibid, 9.

Ibid, 15. 
anchored in the everyday in their telling. In this reading, the assembly of a dialogue is all about focusing our attention on the ordinary, on its fragility and the necessity of its repair.

But what of the scenes of cityscapes that are woven into the filmic conversation? After all, these landscapes and cityscapes add up to a considerable portion of the film, and are something that a hurried visitor might become impatient with because they interrupt the 'real' story, the one about events. Why this dock, that ship passing, the loading of those cars? Are they Mercedes cars they are loading? If so, what does that mean? Why that building, that fence, that street, that church? Are they just to give context, allowing us to place the actions being narrated in the spaces of a concrete, real city? Or could a kind of symbolism be going on: could the Maersk freighter represent global multinational capital that doesn't give a fig for African workers, and could the Mercedes dealer represent empty, mindless consumption?

The fact is that there is nothing didactic about the film; it has no teaching, no pedagogical points to get across. It makes no conventional political argument. In these scenes the camera is placed by a harbour, on a dock, in a park, simply in order to see, to record, to be there. Each shot seems not so much to assert a social meaning as to offer to take us into reflection, entering a state of contemplation, of witnessing. There is no imperative: 'Fit this scene into some broader social, political, economic, canvas!' But rather an invitation: 'OK, stand here next to me, be right here. Here it is. This is what we work with. This is all we have but all we need.' Laugier cites a phrase from Cavell that neatly evokes this witnessing: the scenes are invitations to imagine 'a return to a place where one has never been. ${ }^{10}$ In the context of a 'return to the ordinary', these shots appear as moments of suspension in which we remember that there is no normal scene, no ordinary moment, without vulnerability; these are scenes that put their own fragility on display. The shots say: here is where we do the work of repair.

Exiting Red, I find myself thinking about another car, not a Mercedes but a more modest vehicle, a Trabant, the car of the German Democratic Republic, that now sits in the Museum of the DDR in Berlin. This is a car not red, it's a hard-to-describe milky yellow-grey-green. Along with all the other objects in the museum, it contributes to a simple goal: to construct an opinion about something we are led by the vast amount of explanatory text to call the pathetic quality of everyday life under socialism. It provokes not reflection but the recitation of a lesson learnt by rote: the socialist era was a disaster, the GDR was a caricature of a society. In fact the entire museum shows an inability to reflect on or even recognise the problem of how an entire society, the GDR, could be smoothly absorbed into another society alien in many ways to its forms of life. And if it is impossible for one group of culture makers in Europe's largest, richest country to admit this, then what about the work of repair in the countries of the former Yugoslavia, in Bosnia, Croatia, Serbia? And in Africa, and 
everywhere else in the world where the work of repair is not an annoying distraction from comfort but an urgent necessity for civic life?

We know that the work of repairing our broken, fragile ordinaries goes on. It is on display in one of Europe's most curious museums, Zagreb's "Museum of Broken Relationships," a concept-space that resonates on the same artistic frequency as Red. The entire museum is a kind of installation. It consists of a few small rooms on the first floor of an old building around the corner from Croatia's government square, filled with completely ordinary objects - a shoe, an empty can of beer, a stuffed animal sitting in a case or hung on a wall - given context only by brief narratives written by their one-time owner and displayed nearby. These various things point to the collapse of that most mysterious of human creations, a relationship, a union of autonomous beings. The stories convey immense pain, sadness and despair at what was lost, but they also amount to (and recruit the viewer into) a collective work of repair. This recruitment is what stays with me as I wonder, finally, here at the crossroads of Red, which way to go. 